\title{
Exploration, Isolation and Quantification of $\beta$-carotene from Bacterial Symbion of Acropora sp.
}

\author{
NAELY KURNIA WUSQY ${ }^{1 *}$, LEENAWATY LIMANTARA ${ }^{2}$, \\ AND FERRY FREDY KARWUR ${ }^{1}$ \\ ${ }^{I}$ Satya Wacana Christian University, Salatiga, 50711, Central Java, Indonesia; \\ ${ }^{2}$ Ma Chung Research Center for Photosynthetic Pigments, Universitas Ma Chung, Malang 65151, \\ East Java, Indonesia
}

\begin{abstract}
In the microbial world, pigments are one of the most conspicuous traits. Marine bacteria associated with Acropora sp. collected from Taka Cemara, Karimunjawa Islands were screened for the production of a yellow pigment. The isolation of bacterial symbionts from Acropora sp. on Zobell 2216E medium resulted in one bacterium, KJ5, positively synthesized carotenoids. By reverse phase HPLC analysis, one peak of the pigment types was identified as a $\beta$-carotene peak which appeared at $60.24 \mathrm{~min}$. Then, sample of the $\beta$-carotene was collected and identified according to their spectral characteristics and compared with the published data in different types of solvent. Based on the HPLC analysis, the total $\beta$-carotene contents were calculated by converting the broad absorption of $\beta$-carotene. Molecular identification of the bacterium KJ5 using $16 \mathrm{~S}$ rDNA showed that bacterium KJ5 was closely related to Erythrobacter flavus with $96 \%$ homology value.
\end{abstract}

Key words: 16S RDNA, Acropora sp., $\beta$-carotene, Erythrobacter flavus, HPLC

Bakteri laut berwarna kuning telah berhasil diisolasi dari karang lunak Acropora nasuta yang berasal dari Taka Cemara, Karimunjawa, Jawa Tengah. Dari hasil skrining pada media ZoBell 2216E ditemukan satu isolat KJ5 yang diduga mengandung karotenoid. Identifikasi karoten dengan fase terbalik kromatografi cair kinerja tinggi (KCKT) berhasil mengidentifikasi keberadaan $\beta$-karoten yang muncul pada menit ke 60,24. $\beta$-karoten murni diperoleh dengan menampung hasil KCKT yang selanjutnya dianalisa dengan UV-Tampak. Spektra diidentifikasi sesuai dengan karakteristiknya dan dibandingkan dengan referensi lain dalam berbagai jenis pelarut. Identifikasi spesies bakteri yang dilakukan menggunakan reaksi berantai polimerase, menunjukkan bahwa isolat bakteri KJ5 memiliki homologi sebesar 96\% dengan Erythrobacter flavus.

Kata kunci : $\beta$-karoten, Acropora sp., Erythrobacterflavus, HPLC, 16S RDNA

Natural pigments with an annual growth rate of 5 $10 \%$, have now comprised $31 \%$ of the worldwide colorant market compared to $40 \%$ for synthetic colorants (Downham and Collins 2000; Mapari et al. 2010). Natural $\beta$-carotene is an orange-yellow pigment of carotenoid family that is widely used as a food colorant. $\beta$-carotene is very attractive as natural food colorant due to its antioxidant and pro-vitamin activities which provide additional value to the products (Paz et al. 2012). Recently, the price of extracted and purified natural $\beta$-carotene is much higher than that of synthetic $\beta$-carotene ( $\$ 1000$ to $\$ 2000$ kilogram-1 for natural versus $\$ 400$ to $\$ 800$ kilogram-1 for synthetic). The price difference reflects that the consumers prefer the natural products to the synthetic $\beta$-carotene (Caswell and Zilberman 2000).

*Corresponding author; Phone: $+62-85842278789$, Email: naely_wusqy@yahoo.com
Many of the heterotrophic bacteria that synthesize carotenoids have been isolated from coastal and oceanic waters (Du et al. 2006). The widespread occurrence of carotenoids in non-phototrophic bacteria suggests that theirpresence is crucial for the viability of these organisms in their natural environment. Due to the absence of photosynthetic apparatus, the importance of the carotenoids in these microorganisms lies mainly in protecting the microbes from photooxidative damage and in absorption of visible light (Britton et al. 1995). In this work, we reported the identification of a marine bacterium associated with soft coral Acropora nasuta and its potential for the productionof $\beta$-carotene.

\section{MATERIALS AND METHODS}

Collection of Samples and Bacterial Isolation. Colonies of soft coral Acropora nasuta were collected 
from Taka Cemara Karimunjawa waters manually. Upon collection colonies were put into sterile plastic bags (Whirl-Pak, Nasco, USA) and put into a cool-box. The tissues were then rinsed with sterile seawater and cut with a sterile knife. The resultant tissues were serially diluted, spread on $1 / 2$ strength ZoBell $2216 \mathrm{E}$ marine agar medium and incubated at room temperature for $48 \mathrm{~h}$. On the basis of morphological features, 9 colonies were randomly picked and purified by making streak plates (Madigan et al.2000).

16S rDNA Polymerase Chain Reaction. The universal primers 27F (5'-AGAGTTTGATCMTGGC TCAG-3') and primer 1492R (5'-TACGGYTACCTT GTTACGACTT-3') were used to amplify 16S-rDNA gene (Long and Azam 2001). The temperature cycle of amplification was as follows: initial denaturation at a temperature of $94{ }^{\circ} \mathrm{C}$ for $2 \mathrm{~min}$, and then successive denaturation $\left(94{ }^{\circ} \mathrm{C}\right.$ for $\left.1 \mathrm{~min}\right)$, annealing $\left(55^{\circ} \mathrm{C}\right.$ for 1 $\mathrm{min})$, andextension $\left(72{ }^{\circ} \mathrm{C}\right.$ for $\left.2 \mathrm{~min}\right)$. Series of denaturation, annealing and extension wererepeated until 45 cycles. Electrophoresis was done on $2 \%$ agarose. Sequencing was done according to Radjasa et al. (2007). Homology search and DNA data bank by BLAST (Atschul et al. 1997).

Extraction of Pigments. Ten plates of bacterial symbiontswhichwere cultured on Zobell agar medium were collected and their pellets moisture was measuredby balancing moisturizer. Then, $10 \mathrm{~mL}$ of
$100 \%$ acetone were added into pellets for extraction (Khalil and Varananis 1996), with the aid of a sonicator (Britton etal. 1995).

Identification and Analysis of $\boldsymbol{\beta}$-carotene. $\beta$ carotene was identified and analyzed by using High Performance Liquid Chromatography in reverse phase column AB with ODS, C18, diameter of $4 \mathrm{~mm} \times 25$ $\mathrm{mm}$. The method used consists of an elution gradient of methanol, acetone and ammonium acetate solution (1 M), similar to the method used by Hegazi et al. (1998). The flow-rate was $1 \mathrm{~mL} \mathrm{~min}^{-1}$, and the gradient protocol lasted approximately $80 \mathrm{~min}$. All these steps were carried out at room temperature. Peak of $\beta$ carotene which appeared at 60.24 min was collected and identified according to their spectral characteristics and compared with the published data in different types of solvent.

\section{RESULTS}

Sampling and Isolation of Bacterial Symbionts. Acropora nasuta samples used in this study were taken from Taka Cemara, Karimunjawa Islands (Fig 1A). One isolate, namely KJ5 (Fig 1B) which was found to produce yellow pigment was expected as source of carotenoids. A total of $200 \mathrm{~g}$ wet weight of KJ5 isolate were extracted, resulted in $0.42 \mathrm{~g}$ of yellow pigments with $47.10 \%$ moisture.

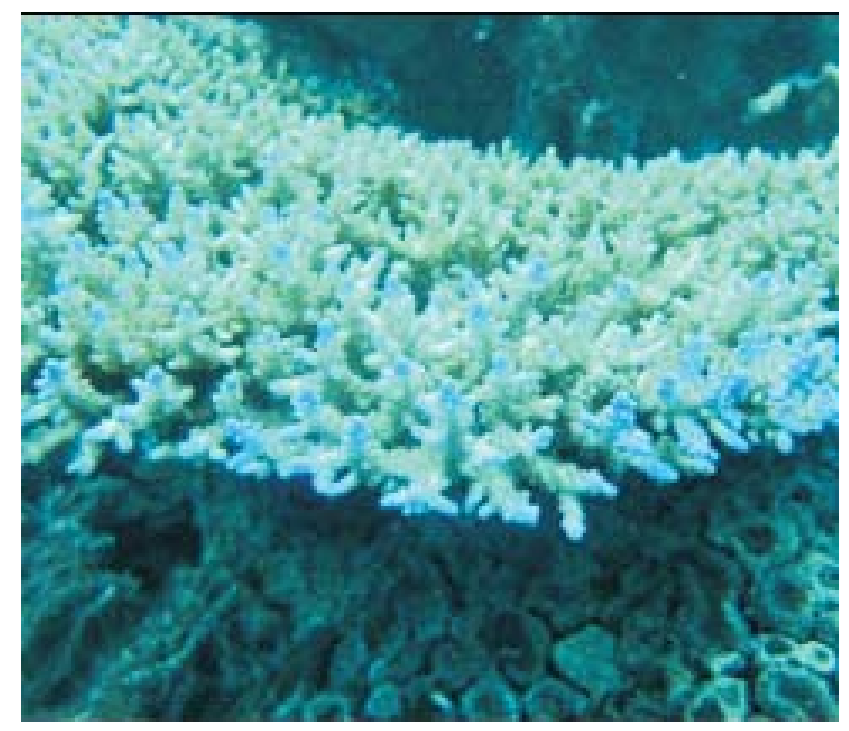

A

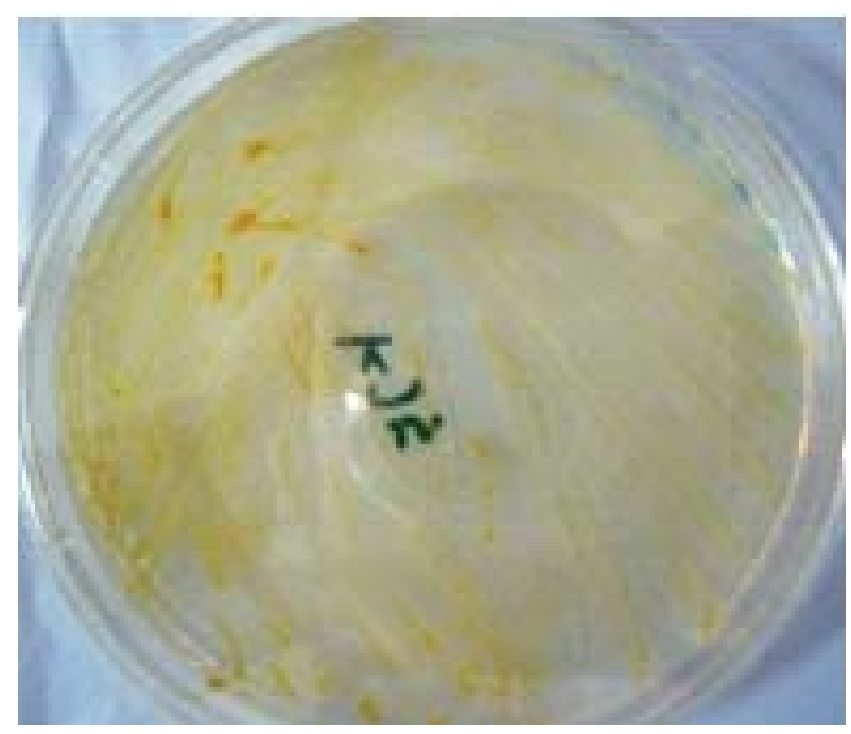

B

Fig 1 Sample of Acropora nasuta from Taka Cemara, Karimunjawa, Jepara (A); Sample of KJ5 isolate (B). 


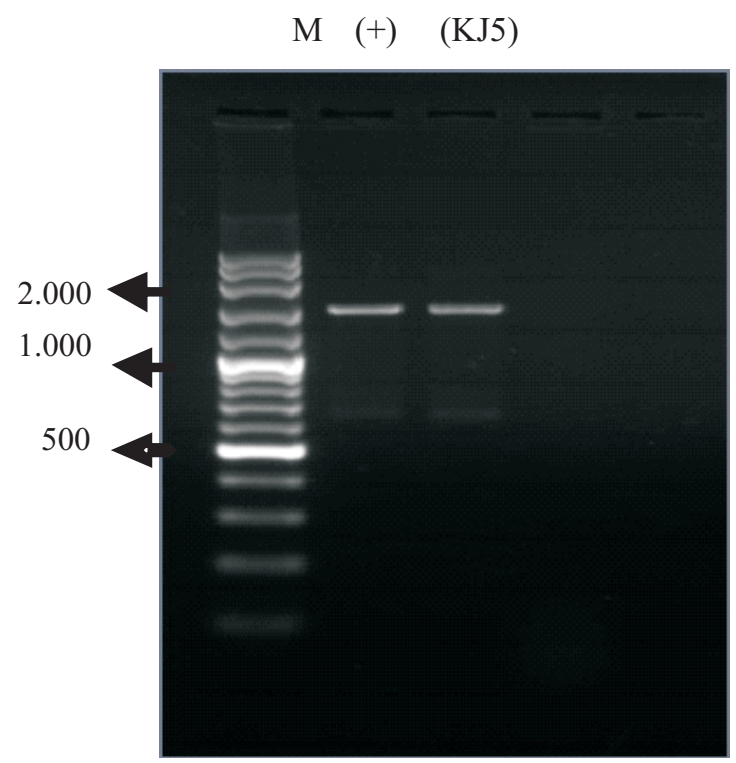

Fig 2 PCR Amplification of 16s rDNA fragment. M: Marker; (+): positive control; KJ5: sample.

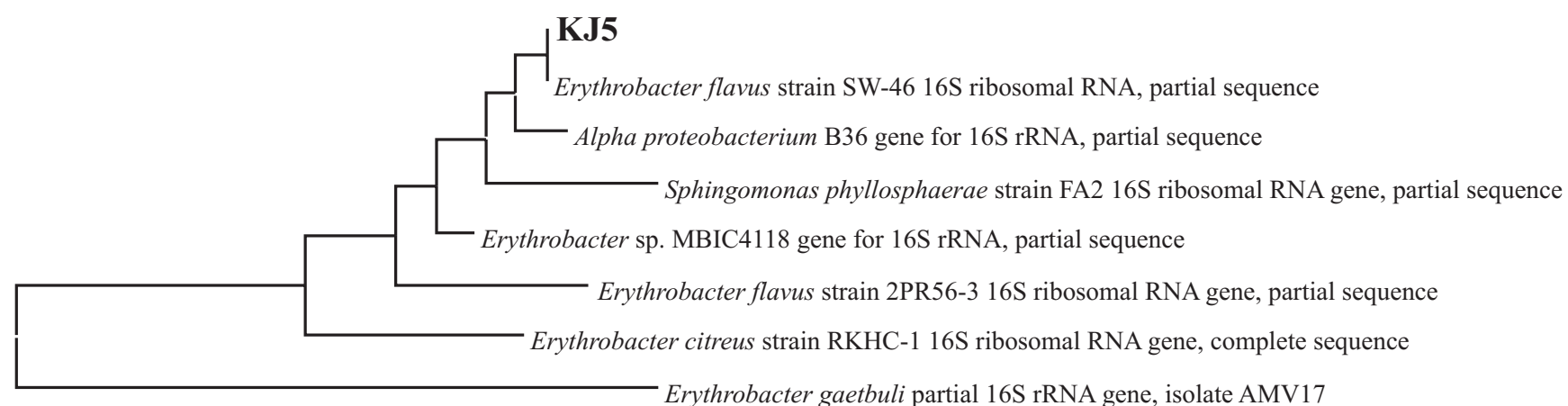

Erythrobacter gaetbuli partial 16S rRNA gene, isolate AMV17

$$
0.002
$$

Fig 3 Phylogenetic tree based on 16S rRNA gene sequences of strain KJ5 and representative members of related species of the genus Erythrobacter.

Table 1 Molecular Identification of KJ5 isolate

\begin{tabular}{cccc}
\hline Code & Length & Closest Relative & Homology \\
\hline KJ5 & 1440 bp & Erythrobacterflavus & $96 \%$ \\
\end{tabular}

DNA amplification of isolate KJ5 using 16S rDNA PCR showed positive results with the presence of bacterial DNA isolate KJ5 with the appropriate base length of approximately 1500 bp (Fig 2). Phylogenetic tree shown in Fig. 3 shows the phylogenetic affiliation of bacterial isolate with other microorganisms. Molecular identification, by two directions sequencing of the PCR product, showed that isolate KJ5 has the highest percentage of similarity with Erythrobacter flavus strain with a 96\% level value (Table 1).

From the results of HPLC analysis during $80 \mathrm{~min}$, we found the $\beta$-carotene absorption wavelength of 427, 449 and $477 \mathrm{~nm}$ at $60.24 \mathrm{~min}$ (Fig 8) (Hegazi et al. 1998). The spectra of HPLC pigment pattern of KJ5 


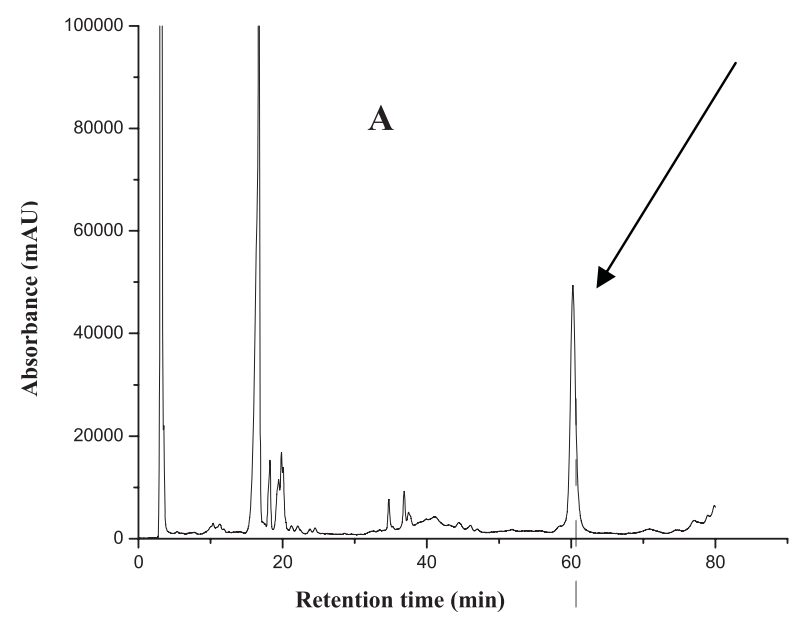

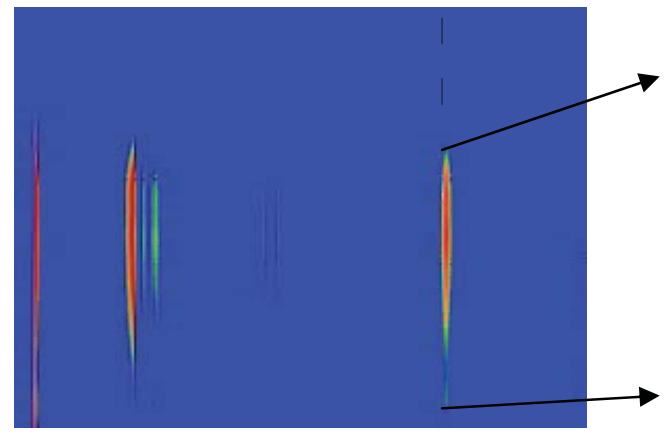

B

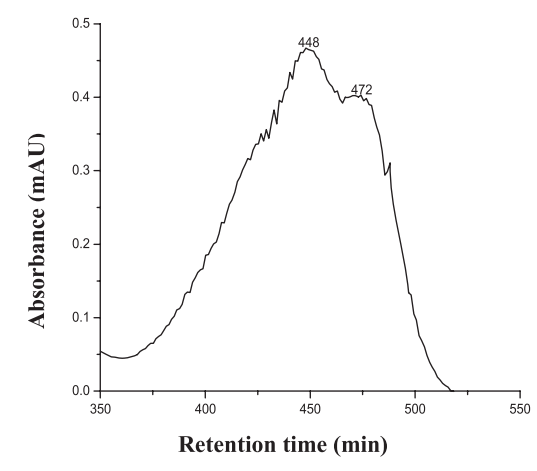

C

Fig. 4 High-performance liquid chromatogram of acetone extract from Erb. Flavus at 450 nm wavelength (A); 2 dimension of extract pigment of Erb. flavus (B); Absorption maxima of $\beta$-carotene extract at 60,24 min by UV-Vis spectroscopy (C).

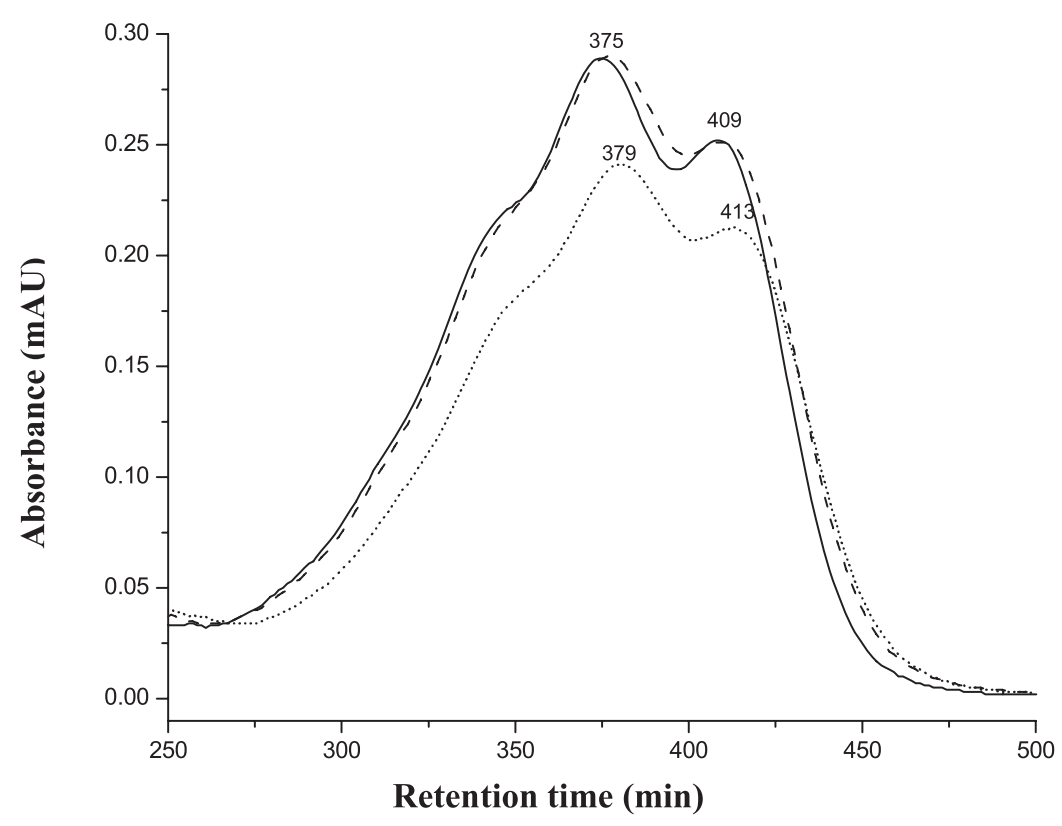

Fig. 5 The spectra of HPLC pigment pattern of KJ5 isolate at three different solvents; acetone (..); ethanol (--) and hexane (-) at 300-500 nm wavelengths. 
isolate at three different solvents (Fig 5), and table 2 gives the absorption maximum of the pigments in various solvents.

Based on the HPLC analysis results that the maximum absorbance of $\beta$-carotene for this sample was in at a $\mathrm{t}_{\mathrm{R}} 59.73-60.65$ (Fig 4), the total $\beta$-carotene contents were calculated. The total $\beta$-carotene extracted from the Erb. flavus sample was 0,421 gr. The concentration of total $\beta$-carotene per gram of Erb. flavus can be calculated according to the following formula:

$$
\text { Yield }(\mu \mathrm{g} / \mathrm{mL})=\mathbf{0 . 0 1 0 8 x}+\mathbf{1 2 . 6 7 7}
$$

(Limantara et al. 2013)

The concentration of total $\beta$-carotene per gram of wet weight of Erb.flavus is $30.01 \mathrm{~g} / \mathrm{g}$ or $56.74 \mu \mathrm{g} / \mathrm{g}$ of dry weight.

\section{DISCUSSION}

Erythrobacter flavus was proposed by Yoon et al., (2003). The characteristics of these bacteria are nonspore-forming rods, gram-staining reaction is negative, and motile by means of a single polar flagellum. Colonies are yellow, smooth, glistening, circular, convex with entire margins and 10-15 $\mathrm{mm}$ in diameter after $3 \mathrm{~d}$ cultivation at $30{ }^{\circ} \mathrm{C}$ on MA. Optimal temperature for growth is $30-37^{\circ} \mathrm{C}$. Growth occurs at 10 and $42{ }^{\circ} \mathrm{C}$, but not at $4{ }^{\circ} \mathrm{C}$ or above $43{ }^{\circ} \mathrm{C}$. Optimal $\mathrm{pH}$ for growth is 6.5-7.5 (Yoon et al. 2003). Most species of this genus contain bacteriochlorophyll $\alpha$ and carotenoids (Shiba and Simidu 1982; Yurkov et al. 1994).

The HPLC absorbant chromatogram is shown highlighting the separation of the pigment from Erb.flavus. UV-visible absorption spectra of carotenoid pigments are of immense importance, since they aid a great deal in determining the structure of carotenoids (Medicharla et al. 1991). From the HPLC profile and UV-visible absorption spectra, we can conclude that Erb.flavus produces a $\beta$-carotene type of carotenoid pigment that has many potential benefits.

From the data it was evident that Erb.flavus produced less than $\beta$-carotene as compared to other microorganisms e.g. Dunaliella salina (Prieto et al. 2011), fungi Phycomyces blakesleeanus (Murillo et al. 1978), and Blakeslea trispora mutant (Mehta et al. 1997). However, the $\beta$-carotene content reported in this study was higher than Streptomyces sp. which produced $4.88 \mu \mathrm{g}$ per 100 gram (Baskar et al. 2010), Erb.flavus has been shown to have a potential strain for $\beta$-carotene production. The maximal $\beta$-carotene yield was $56.74 \mu \mathrm{g} \mathrm{L}^{-1} \mathrm{~g}$ of dry weight. These results suggest that strain KJ5 is worthy of further study for $\beta$-carotene industrialization.

Table 2. List of $\beta$-carotene spectral data from several data in the mobile phase and different solvents. where $\mathrm{x}$ is the broad absorption of the $\beta$-carotene, $y$ is the concentration $\left(\mu \mathrm{g} \mathrm{mL}^{-1}\right)$

\begin{tabular}{lcccc}
\hline \multicolumn{1}{c}{ References } & Acetone & Ethanol & Hexane & Eluent \\
\hline Britton et al. & - & $425,450,478$ & - & - \\
$(1995)$ & & & & \\
\hline Jeffrey et al. & $426,453,480$ & $427,449,475$ & $422,450,477$ & $425,453,476$ \\
$(1997)$ & $(\mathrm{III} / \mathrm{II}=21 \%)$ & & $(\mathrm{III} / \mathrm{II}=36 \%)$ & $(\mathrm{III} / \mathrm{II}=22 \%)$ \\
\hline Hegazi et al. & - & - & $425,449,477$ & $428,452,476$ \\
$(1998)$ & & & & \\
\hline Results & $429,451,480$ & $429,454,479$ & $426,450,476$ & $427,449,477$ \\
& $(\mathrm{III} / \mathrm{II}=20 \%)$ & $(\mathrm{III} / \mathrm{II}=11 \%)$ & $(\mathrm{III} / \mathrm{II}=33 \%)$ & $(\mathrm{III} / \mathrm{II}=13 \%)$ \\
\hline
\end{tabular}

Table 3 Broad absorption, yield and dry weight of $\beta$ carotene

\begin{tabular}{ccc}
\hline Broad absorption $(\mathrm{x})$ & Y ield & Conc $(\mu \mathrm{g} / \mathrm{g}$ dry weight $)$ \\
\hline 1166.17 & 12.64 & 56.74 \\
\hline
\end{tabular}




\section{ACKNOWLEDGMENT}

We wish to acknowledge the advice and all support of Ocky K. Radjasa for this manuscript. We would also like to thank Majid Khoeri for some of the sequencing, Indriatmoko and Lia Kusmita for pigment analysis. This work was supported by the Indonesian Ministry Education and Culture.

\section{REFERENCES}

Altschul SF, Madden TL, Schaffer AA, Zhang J, Zhang Z, Miller W, Lipman DJ. 1997. Gapped BLAST and PSIBLAST: a new generation of protein database search programs. Nucleid Acid Res. 25: 33893402.doi10.1093/nar/25.17.3389.

Baskar V, Madhanraj P, Kanimozhi K, Panneerselvam A. 2010. Characterization of Carotenoids from Streptomyces sp. of marine and fresh water environment. Arch Appl Scie Res .2 (6): 380-388.

Britton G, Liaaen-Jensen S, Pfander H. 1995.Carotenoid. Birkäuser Verlag Basel. Boston. Berlin.

Caswell M, Zilberman D. 2000. Algolculture.Economic Research Service, USDA Department of Agricultural and Resource Economics, University of California at Berkeley: 1-10.

Downham A, Collins P. 2000. Colouring our foods in the last and next millennium. Int $\mathrm{J}$ Food Sci Technol. 35(1):5-22. doi:10.1046/j.1365-2621.2000. 00373.x.

Du HL, Jiao NZ, Hu YH, Zeng YH. 2006. Diversity and distribution of pigmented heterotrophic bacteria in marine environments. FEMS Microbiol Ecol. 57(1): 92-105. doi: 10.1111/j.1574-6941.2006.00090.x.

Hegazi MM, Perez-Ruzafa A, Almela L, Candela ME. 1998. Separation and identification of chlorophyll and carotenoids from Caulerpaprolifera, Janiarubens, and Padinapavonica by reversed-phase high-performance liquid chromatography. J Chromatography. 829 :153159.doi0021-9673/98/\$.

Khalil IA, Varananis FR. 1996. Carotenoid extraction and analysis by reversed phase HPLC system. Sarhad J Agric. 105(67): 15-21.

Limantara L, Heriyanto, Indriatmoko, Mucko P, Adhiwibawa MAS, Indrawati R, Priharyanti MNU, Brotosudarmo THP. 2013. Variation on chlorophylls and carotenoids composition from Kappaphycus alvarezii and Padina australis grown in three different locations in Indonesia (Jepara beach, Madura Island and Maluku Island). J Appl Phys. (Submitted).
Long RA, Azam F. 2001. Antagonistic Interactions among Marine Pelagic Bacteria. Appl Environ Microbiol. 67 (11): 4975-4983.doi10.1128/AEM.67.11.49754983.2001.

Madigan MT, Martinko JM, Parker J. 2000. Brock Biology of Microorganisms. Prentice Hall. New Jersey.

Mapari SAS, Thrane U, Meyer AS. 2010. Fungal polyketideazaphilone pigments as future natural food colorants? Trends in Biotechnol 28 (6): 300-307. doi: 10.1016/j.tibtech.2010.03.004.

Jagannadham MV, Rao VJ, Shivaji S. 1991. The major carotenoid pigment of a psychrotrophic Micrococcus roseus strain: Purification, structure and interaction with synthetic membranes. J Bacteriol. 173:79117917.doi: 0021-9193/91/247911-07\$02.00/0.

Mehta BJ, Salgado LM, Bejarano ER, Cerdá-Olmedo E. 1997. New mutants of Phycomyces blakesleeanus for $\beta$-carotene production. Appl Environ Microbiol. 63: 3657-3661.doi: 10.1128/AEM.69.7.40434048.2003.

Murillo FJ, Calderon IL, Lopez-Diaz I, Cerdá-Olmedo E. 1978. Carotene-super producing strains of Phycomyces. Appl Environ Microbiol. 36 (1978) 639-642.doi: 0099-2240/78/0036-0639\$02.00/0.

Paz EDA, Martin A, Estrella A, Rodríguez-Rojo S, Matias AA, Duarte CMM, Cocero MJ. 2012. Formulation of $\beta$ carotene by precipitation from pressurized ethyl acetate-on-water emulsions for application as natural colorant. Food Hydrocolloids 26(1):17-27. doi:10.1016/j.foodhyd.2011.02.031.

Prieto A, Canavate JP, Garcia-Gonzalez M. 2011. Assessment of carotenoid production by Dunaliella salina in different culture systems and operation regimes. J Biotechnol. 151(2):180-185. doi: 10.1016/j.jbiotec.2010.11.011.

Radjasa OK, Martens T, Grossart HP, Brinkoff T, Sabdono A, Simon M. 2007. Antagonistic activity of a marine bacterium Pseudoalteromonas luteoviolacea TAB4.2 associated with coral Acropora sp. J Biol Sci. 7(2): 239246. doi: 10.3923/jbs.2007.239.246.

Shiba T, Simidu U. 1982. Erythrobacter longus gen. nov., sp.nov., an aerobic bacterium which contains bacteriochlorophyll $a$. Int $\mathrm{J}$ Syst Bacteriol. 32:211-217.doi: 10.1099/00207713-32-2-211.

Yoon JH, Kim H, Kim HG, Kang KH, Park YH. 2003. Erythrobacter flavus sp. nov., a slight halophile from the East Sea in Korea. Int J Syst Evol Microbiol. 53, 1169-1174.doi 10.1099/ijs.0.02510-0.

Yurkov VV, Stackebrandt E, Holmes A, Fuerst J, Hugenholtz P, Golecki J, Gad'on N, Gorlenko V, 
Kompantseva E, Drews G. 1994. Phylogenetic positions of novel aerobic, bacteriochlorophyll acontaining bacteria and description of Roseococcus thiosulfatophilusgen. nov., sp. nov., Erythromicrobium ramosum gen. nov., sp. nov., and Erythrobacter litoralis sp. nov. Int J Syst Bacteriol. 44:427-434. doi: 0020-7713/94/\$04.00+0. 